\title{
O nowe prawo do grobu? Glosa krytyczna do wyroku Sądu Najwyższego z dnia 24 czerwca 2019 roku, III CSK 267/17
}

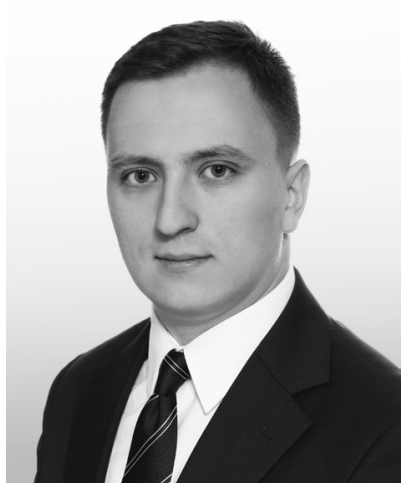

\section{Patryk Walczak}

Doktorant w Szkole Doktorskiej Nauk Społecznych Uniwersytetu Jagiellońskiego $w$ dyscyplinie nauki prawne, sekretarz redakcji czasopisma „Forum Prawnicze”. Przygotowuje w Katedrze Prawa Rzymskiego UJ rozprawę doktorska o ustanowieniu dziedzica pod warunkiem lub z zastrzeżeniem terminu w zachodniej tradycji prawnej.

$\bowtie$ patryk.walczak@doctoral.uj.edu.pl https://orcid.org/00oo-0002-6053-6689
The New Right of Burial? A Critical Commentary to the Decision of the Supreme Court of 24.6.2019, Ref. III CSK 267/17

\begin{abstract}
This paper concerns the concept of the right of burial, developed in the jurisprudence and upheld in the commented decision. The heterogeneous concept of the right of burial - the patrimonial rights in the case of an empty grave and non-patrimonial rights, when someone is already buried in the grave - has been adopted. Such a classification has consequences in the inheritability and transferability of this right, especially in this second form. The judiciary has created, in the name of the proper protection of the personal rights of the deceased's relatives, indirectly, the alternative succession proceedings concerning the non-patrimonial right of burial. It seems, however, that this concept does more harm than good. The broader legal protection is only illusory, creates uncertainty in the legal system, unnecessary costs and non-intuitive legal solutions. It raises concerns whether an a priori rejection of the homogeneous concept of the right of burial conducted in case law is rational.
\end{abstract}

Słowa kluczowe: prawo do grobu, dziedziczność, prawo majątkowe, dodatkowe postępowanie spadkowe, sukcesja syngularna na wypadek śmierci

Key words: right of burial, inheritability, patrimonial rights, alternative inheritance proceedings, singular succesion mortis causa https://doi.org/10.32082/fp.vli1(57).301

W ciągu ostatnich 50 lat w orzecznictwie Sądu Najwyższego wykształciła się utrwalona linia orzecznicza dotycząca istoty prawa do grobu ${ }^{1}$. Ogromna rola

1 Uchwała SN z dnia 7 grudnia $1970 \mathrm{r}$., III CZP 75/70; wyrok SN z dnia 
sądów w kształtowaniu tej kategorii prawnej jest wymuszona fragmentaryczną jej regulacją przez ustawodawcę i rozbieżnościami interpretacyjnymi. Elementarne założenie, na którym zasadza się cała koncepcja wykształcona w orzecznictwie, to niejednorodny charakter prawa do grobu - majątkowy w przypadku pustego grobu i niemajątkowy w razie gdy w grobie zostało już złożone ciało. W konsekwencji pusty grób, a nawet jego poszczególne miejsca pochówkowe pozostają przedmiotem obrotu - jednak do momentu złożenia tam pierwszych zwłok. To zdarzenie skutkuje wyłączeniem z obrotu i pozbawieniem przymiotu zbywalności oraz dziedziczności. Następstwem przyjętego założenia jest niepewność obrotu wynikająca ze stanu zawieszenia co do rzeczywiście uprawnionego oraz konieczność każdorazowego ustalania przez sąd, komu przysługuje prawo do grobu w przypadku śmierci wyłącznego dysponenta. Co więcej, ta procedura jest rozstrzygnięciem $\mathrm{w}$ istocie równoległym do postępowania spadkowego o sukcesji syngularnej mortis causa dóbr niematerialnych.

\section{Stan faktyczny}

W rozstrzyganej sprawie powódka wraz z mężem nabyła w 2001 r. od osoby, która w procesie wystąpiła jako interwenient uboczny, za kwotę 10 tysięcy złotych prawo do dysponowania dwoma z pięciu miejsc pochówkowych znajdujących się w pustym grobie. Sprzedający po zawarciu umowy wystosował dyspozycję do zarządu cmentarzy komunalnych, by nabywcy zostali wpisani do ksiąg cmentarnych jako dysponenci dwu miejsc na wypadek jego śmierci ${ }^{2}$, nigdy jednak nie zrzekając się dysponowania prawem do grobu w całości. Na potwierdzenie zawartej umowy został z nagrobka usunięty napis o grobie rodzinnym interwenienta.

13 lutego 1979 r., I CR 25/79; uchwała SN z dnia 2 grudnia 1994 r., III CZP 155/94; wyrok SN z dnia 7 listopada 2002 r., II CKN 980/00; wyrok SN z dnia 29 stycznia 2003 r., I CKN 1453/00; wyrok SN z dnia 7 maja 2009 r., IV CSK 513/08; wyrok SN z dnia 9 grudnia 2011 r., III CSK 106/11; wyrok SN z dnia 17 lutego 2016 r., III CSK 84/15.

2 Zjawisko rozporządzania majątkiem na wypadek śmierci już za życia można ocenić jako świadectwo nieefektywności instrumentów prawa spadkowego.
Kilka lat później małżonek powódki zmarł, a była ona jego wyłączną spadkobierczynią w drodze dziedziczenia ustawowego, nabywając majątkowe prawa pochówkowe do pustego grobu (dwa miejsca). Korzystając z przysługujących jej uprawnień, na początku 2013 roku złożyła ciało swojego zmarłego męża w grobie, który stanowi przedmiot sporu. Następnie na podstawie art. 189 k.p.c. pozwała zarząd cmentarza, wnosząc o ustalenie istnienia na jej rzecz wyłącznego prawa do grobu. Uzasadniła to faktem pochowania tam swego męża, oceniając, że powstało w związku $\mathrm{z}$ tym prawo kultu pamięci.

$\mathrm{Z}$ uwagi na niemajątkowy charakter prawa do grobu zarówno sąd okręgowy, jak i sąd apelacyjny właściwe w sprawie ${ }^{3}$ uznały, że powódce przysługuje prawo do dysponowania grobem w związku z dobrami osobistymi - w postaci kultu pamięci jej zmarłego męża ${ }^{4}$. Przysługuje jej więc prawo do czegoś więcej niż dysponowanie miejscem pochówkowym, jednak nie stanowi to podstawy do uznania, że jest ona jedyną uprawnioną do dysponowania. Sądy powszechne potwierdziły przysługiwanie tego prawa równolegle interwenientowi ubocznemu, a sąd apelacyjny podkreślił ponadto, że pochowanie męża powódki w grobie nie powoduje utraty przez interwenienta prawa do dysponowania pozostałymi miejscami pochówkowymi i innymi prawami majątkowymi składającymi się na prawo do grobu.

3 Zgodnie z ustawą z dnia 17 listopada 1964 r. - Kodeks postępowania cywilnego (tekst jedn. Dz.U. z 2019 r., poz. 1460), dalej: k.p.c., „do właściwości sądów okręgowych należą sprawy: 1) o prawa niemajątkowe i łącznie z nimi dochodzone roszczenia majątkowe oprócz spraw o ustalenie lub zaprzeczenie pochodzenia dziecka, o ustalenie bezskuteczności uznania ojcostwa oraz o rozwiązanie przysposobienia" (art. 17 pkt 1 k.p.c.).

4 Katalog dóbr osobistych wskazanych w art. 23 ustawy z dnia 23 kwietnia 1964 r. - Kodeks cywilny (tekst jedn. Dz.U. z 2019 r., poz. 1145), dalej: k.c., ma charakter wyłącznie przykładowy. Stąd kult pamięci osoby zmarłej można zaliczyć do kategorii dóbr osobistych. Zob. Ł. Cudny, K. Kryla, Kult pamięci osoby zmarłej jako dobro osobiste, „Monitor Prawniczy” 2011, nr 16, s. 897 i n.; K. Matuszewski, Pamięć i kult osób zmarlych jako autonomiczne dobro osobiste, „Monitor Prawniczy" 2012, nr 20, s. 1085-1086. 


\section{Kwalifikacja prawna SN}

Na wstępie rozważań Sąd Najwyższy słusznie zaznaczył, że sformułowanie „prawo do grobu” nie jest terminem ustawowym, legalnym; obejmuje ono „szereg wzajemnie sprzężonych uprawnień o charakterze majątkowym i niemajątkowym"5. Zaraz jednak podkreślił, że prawo odnoszące się do grobu, w którym nie pochowano jeszcze żadnej osoby, ma charakter mniane wyżej prawa niemajątkowe wynikające z dóbr osobistych powódki mają charakter dominujący względem uprawnień majątkowych wynikających z umowy z zarządem cmentarza ${ }^{8}$. W konsekwencji wykonywanie praw majątkowych ulega ograniczeniu, a samo prawo do grobu zmienia swoją istotę na niematerialną z uwagi na prymat dóbr o charakterze osobistym względem dóbr majątkowych w kodeksie cywilnym ${ }^{9}$.

\section{W orzecznictwie SN prawo do grobu jest zmienne - majątkowe dla pustych grobów, a niemajątkowe po złożeniu w grobie pierwszych zwłok.}

wyłącznie majątkowy ${ }^{6}$. W konsekwencji jest to prawo zbywalne i dziedziczne ${ }^{7}$, a interwenient uboczny rozporządził nim, a właściwie jego częścią, skutecznie. Potwierdził też, że uprawnienie do dysponowania miejscami pochówkowymi, będące częścią składową prawa do grobu, również ma charakter majątkowy.

Wraz z pochowaniem męża powódki doszło w opinii Sądu Najwyższego do nałożenia się na istniejące wcześniej prawa majątkowe - praw niemajątkowych (osobistych) powódki, które związane były z jej dobrami osobistymi w postaci upamiętniania zmarłego męża. Sąd nie przychylił się do żądania powódki i stanął na stanowisku podzielanym przez sądy powszechne w sprawie, uznając, że nie można mówić o wygaśnięciu dotychczasowych uprawnień interwenienta wskutek pochowania męża powódki w przedmiotowym grobie. W dalszej części SN odrzucił założenie o jednolitym charakterze prawa do grobu i stwierdził, że wspo-

5 Wyrok SN z dnia 13 lutego 1979 r., I CR 25/79; uchwała SN z dnia 2 grudnia 1994 r.; wyrok SN z dnia 7 maja 2009 r., IV CSK 513/08; wyrok SN z dnia 9 grudnia 2011 r., III CSK 106/11; wyrok SN z dnia 17 lutego 2016 r., III CSK 84/15.

6 Uchwała SN z dnia 2 grudnia 1994 r., III CZP 155/94; wyrok SN z dnia 3 grudnia 2010 r., I CSK 66/10; wyrok SN z dnia 14 października 2011 r., III CSK 340/10.

7 J. Sobczak, M. Gołda-Sobczak, Prawo do grobu jako problem kulturowy i prawny, „Zeszyty Naukowe KUL” 2018, t. 60, nr 1 (241), s. 204.
W konsekwencji Sąd Najwyższy przyjął założenie, że prawo do grobu ma dwojaki charakter. Do momentu pochowania w nim pierwszego ciała jest to charakter majątkowy, a uprawnieni do rozporządzania tym prawem, nazywani $\mathrm{w}$ doktrynie dysponentami prawa do grobu, mogą je zbyć i jest ono dziedziczne. Jednak w momencie pochowania tam pierwszej osoby ${ }^{10}$ dochodzi do wyłączenia prawa do grobu z obrotu $\mathrm{z}$ uwagi na niezbywalność praw osobistych ${ }^{11}$ oraz majątkową koncepcję spadku w polskim prawie cywilnym $^{12}$. W konsekwencji prawo do grobu zdaniem SN

8 Wyrok SN z dnia 13 lutego 1979 r., I CR 25/79; uchwała SN z dnia 2 grudnia 1994 r., III CZP 155/94; wyrok SN z dnia 9 grudnia 2011 r., III CSK 106/11; wyrok SN z dnia 3 grudnia 2010 r., I CSK 66/10; wyrok SN z dnia 17 lutego 2016 r., III CSK 84/15.

9 SN w swojej argumentacji przyjął, że dyspozycja art. $142 \$ 1$ k.c. wskazuje na przyjęty przez ustawodawcę ogólny katalog wartości. Zob. A. Machnikowska, Komentarz do art. 142 k.c. (w:) M. Załucki (red.), Kodeks cywilny. Komentarz, Warszawa 2019, nb. 4.

10 Przy założeniu grobu z paroma lub kilkoma miejscami; przy grobie pojedynczym problem wyłączenia z obrotu wskutek pochówku nie występuje.

11 P. Sobolewski, Komentarz do art. 23 k.c. (w:) K. Osajda (red.), Kodeks cywilny. Komentarz, wyd. 24, Warszawa 2020, nb. 11.

12 W. Borysiak, Komentarz do art. 922 k.c. (w:) K. Osajda (red.), Kodeks cywilny..., nb. 92. 
jest niejednorodne oraz zmienne w swej naturze. Może więc ono przyjmować różne postaci, w zależności od zdarzeń faktycznych.

W końcowej części uzasadnienia Sąd Najwyższy odniósł się do zarzutów kasacyjnych, podkreślając, że powstanie uprawnień o charakterze osobistym nie może prowadzić do „wywłaszczenia” interwenienta ubocznego, a wynika to z konstytucyjnej ochrony własności i praw majątkowych. Podkreślił też za Sądem Apelacyjnym, że potencjalną drogą rozwiązywania konfliktów co do dysponowania prawem do grobu $\mathrm{w}$ razie wielości uprawnionych podmiotów może być stosowana w drodze ostrożnej analogii regulacja o współwłasności ${ }^{13}$. Ostatecznie nie podzielił stanowiska powódki i oddalił skargę kasacyjną.

\section{Odpowiedź na stanowisko SN}

Wzorem SN rozważania dotyczące istoty prawa do grobu powinno się rozpocząć od definicji. Podobnie jak w przypadku innych praw podmiotowych "prawo do grobu” to termin wywodzący się z doktryny i orzecznictwa, a jego celem jest usystematyzowanie i zebranie majątkowych uprawnień wynikających $\mathrm{z}$ określonego stosunku prawnego ${ }^{14}$. Ma ono swoje źródło w cywilnoprawnym stosunku zobowiązaniowym wynikającym najczęściej z umowy adhezyjnej między zarządem cmentarza i usługobiorcą, w którym za odpowiednią opłatą zarząd cmentarza udostępnia swojemu klientowi miejsce do pochówku ${ }^{15}$. Ten stosunek prawny można porównać do najmu, w którym wynajmujący udostępnia dobro do używania, a najmujący uiszcza za to świadczenie odpowiednie wynagrodzenie. Sam stosunek może być zróżnicowany w zależności od przedmiotu umowy - ze względu na rodzaj grobu (ziemny bądź murowany) i ze względu na

13 Taka koncepcja była już prezentowana w orzecznictwie, Zob. wyrok SN z dnia 16 maja 1978 r., I CR 57/78; uchwała SN z dnia 29 września 1978 r., III CZP 56/78; por. z wyrokami SN: z dnia 7 maja 2009 r., IV CSK 513/08; z dnia 3 grudnia 2010 r., I CSK 66/10; z dnia 8 maja 2015 r., III CSK 305/14.

14 Poselski projekt ustawy o zmianie ustawy z dnia 7 marca 2013 r. o cmentarzach i chowaniu zmarłych, Sejm VII kadencji, druk nr 1661, przewidywał sformułowanie „prawo do grobu”, nie doszło jednak do jego uchwalenia, s. 3.

15 S. Rudnicki, Prawo do grobu. Zagadnienia cywilistyczne, Kraków 1999, s. 99. liczbę miejsc pochówkowych (grób jednomiejscowy lub składający się z więcej niż jednego miejsca ${ }^{16}$.

Przez groby ziemne rozumie się zagłębienie w gruncie, do którego składa się ciało lub urnę i zasypuje wydobytą ziemią ${ }^{17}$. Murowane natomiast to takie, których ściany boczne są wzniesione $\mathrm{z}$ betonu czy innego trwałego surowca, a nad trumną bądź urną znajduje się sklepienie $^{18}$.Zarówno na groby ziemne, jak i murowane mogą składać się jedno albo więcej miejsc pochówkowych ${ }^{19}$. Miejsca te powstają wskutek zwiększenia szerokości lub głębokości grobu przy uwzględnieniu administracyjnych obostrzeń. Oba rodzaje grobów ziemnych oraz pojedynczy grób murowany przewidziane są na 20 lat od ostatniego pochówku ${ }^{20}$. Przed upływem tego terminu grób nie może zostać ponownie użyty ${ }^{21}$. Każdy zainteresowany istnieniem takiego grobu może uiścić opłatę, która skutkuje przedłużeniem okresu jego funkcjonowania o kolejnych 20 lat. Powyższe zastrzeżenie i uiszczenie opłaty nie rodzą wszakże prawa do grobu po stronie płatnika ${ }^{22}$. Jedynie groby murowane, które składają się z więcej niż jednego miejsca pochówkowego, nie mają charakteru terminowego i nie wymagają dla swego funkcjonowa-

16 Wyrok NSA z dnia 7 września 2017 r., II OSK 27/16.

17 S. Rudnicki, Prawo..., s. 94.

18 Tamże.

19 W aktach wykonawczych do ustawy z dnia 31 stycznia 1959 r. o cmentarzach i chowaniu zmarłych (tekst jedn. Dz.U. z 2019 r., poz. 1473) groby, które składają się z więcej niż jednego miejsca pochówkowego, określa się mianem rodzinnych. Zob. rozporządzenie Ministra Infrastruktury z dnia 7 marca 2008 r. w sprawie wymagań, jakie muszą spełniać cmentarze, groby i inne miejsca pochówku zwłok i szczątków (Dz.U. z 2008 r., nr 48, poz. 284).

20 Art. 7 ustawy o cmentarzach i chowaniu zmarłych.

21 Tamże; zakaz ponownego pochowania nie dotyczy złożenia przez dotychczasowego dysponenta kolejnych zwłok w grobie składającym się z więcej niż jednego miejsca. Występuje on w sytuacji wygaśnięcia prawa do grobu wskutek nieuiszczenia opłaty i powstania po stronie zarządu cmentarza możliwości zawarcia nowej umowy o prawo do grobu, w miejscu gdzie istniał wcześniejszy grób, po uprzednim przeniesieniu szczątków. Zob. Postanowienie WSA w Krakowie z dnia 15 listopada 2019 r., III SA/Kr 588/19.

22 Wyrok SN z dnia 17 września 1986 roku, IV CR 236/86. 
nia uiszczania okresowych opłat ${ }^{23}$ - nie oznacza to jednak, że dysponenci grobów murowanych zwolnieni są z opłaty grzebalnej ${ }^{24}$.

Trudno znaleźć uzasadnienie dla tak poprowadzonej linii demarkacyjnej. Zdaje się bowiem, że wyłączenie terminowości powinno także obejmować groby murowane składające się z jednego miejsca, gdyż to budulec zdaje się być samoistnym czynnikiem determinującym czas przeznaczenia grobu, a nie jego połączenie z liczbą miejsc pochówkowych ${ }^{25}$. Nieprzypadkowo praw niemajątkowych. Należy raczej uznać, że pierwotny majątkowy charakter prawa do grobu pustego nie może ulec zmianie wskutek zewnętrznych zdarzeń faktycznych w postaci złożenia tam pierwszego ciała. Takie okoliczności nie mogą naruszać jego istoty, czyniąc prawo do grobu niemajątkowym wskutek dominacji elementów osobistych nad prawem majątkowym. Zmiana charakteru prawa do grobu w wyniku zmieszania praw niemajątkowych z majątkowymi nie wydaje się bowiem znajdować jakiejkolwiek podstawy prawnej

\section{Zmiana charakteru prawa do grobu $\mathrm{z}$ majątkowego} na niemajątkowy jest konstrukcją wykształconą w orzecznictwie, z której niesłusznie wyciąga się wnioski normatywne.

wszystkie groby murowane w przeszłości określano mianem grobów wieczystych ${ }^{26}$. Należy wobec braku ograniczenia terminowością podkreślić, że nie zwalnia to $\mathrm{z}$ konieczności każdorazowego uiszczenia opłat związanych z pochówkiem.

Rozważając samą istotę prawa do grobu, trudno przyjąć stanowisko Sądu Najwyższego, zgodnie z którym prawo do grobu to zespół uprawnień wynikających z sumy majątkowego prawa do grobu powstałego ze stosunku prawnego $\mathrm{z}$ cmentarzem i związanych $\mathrm{z}$ nim

23 Tak wyrok WSA w Krakowie z dnia 11 marca 2016 roku, III SA/Kr 1360/15, Zob. także https://zck-krakow.pl/pricelists (dostęp 7.01.2020).

24 E. Darmorost, Ustawa o cmentarzach i chowaniu zmarlych. Komentarz, Warszawa 2014, s. 30-31.

25 P. Drembkowski, Ustawa o cmentarzach i chowaniu zmarlych. Komentarz, Warszawa 2018, s. 35. Autor uważa, że z opłat okresowych zwolnione są wszystkie groby murowane.

26 S. Rudnicki, Prawo..., s. 100. Nadal istnieją jednak wątpliwości co do okresu, na jaki przewidziane są groby murowane. Zob. K. Dadańska, A.Tomczyk, Kontrowersje wokół prawa do grobu (w:) J. Gołaczyński i in. (red.), Non omnis moriar. Osobiste i majątkowe aspekty prawne śmierci człowieka, Wrocław 2015, s. 168. i z tego względu próżno szukać jej też w komentowanym orzeczeniu. Bezsporne jest istnienie uprawnień niemajątkowych, jednak należy je rozpatrywać jako zewnętrzne względem majątkowego stosunku prawnego dysponenta z zarządem cmentarza. Jak dobra osobiste związane z odziedziczoną pamiątką rodzinną, często silnie związane ze zmarłym przodkiem, nie łączą się nierozerwalnie z majątkowym prawem własności, tak dobra osobiste związane $\mathrm{z}$ kultem czci zmarłego pochowanego w grobie nie stają się integralną częścią prawa do grobu, a jedynie nań oddziałują. Odrębne rozpatrywanie tych uprawnień nie wpływa na ich zakres czy skuteczność. Pozwala natomiast na większą klarowność terminologiczną i systematyzację.

Niesłusznie Sąd Najwyższy odrzucił bez jakiegokolwiek uzasadnienia koncepcję jednolitego charakteru prawa do grobu. Trudno bowiem znaleźć ratio dla rozpatrywania uprawnień niemajątkowych i majątkowych łącznie, co stanowi konsekwencję wspomnianego wykluczenia. Ta linia argumentacyjna nie tylko nie znajduje oparcia $w$ regulacjach prawnych, ale też i niewiele wnosi do dyskusji nad istotą prawa do grobu, wręcz rozmazując obraz. Nie pozwala na rozłożenie tego stosunku prawnego na czynniki pierwsze i zro- 
zumienie jego istoty. Takie podejście wiązane bywa czasem z tezą o powstawaniu prawa do grobu dopiero $\mathrm{w}$ momencie pochowania pierwszej osoby ${ }^{27}$, co każe postawić pytanie o stan prawny sprzed pochowania, a wręcz o samo istnienie uprawnień strony stosunku zobowiązaniowego $\mathrm{z}$ zarządem cmentarza.

W kwestii prawa do grobu dobrze rozpatrywać wszystkie uprawnienia odrębnie, nie mieszając ich ze sobą. W samym centrum, rzecz jasna, powinno się znajdować prawo do grobu w sensie ściśle majątkowym $^{28}$. Można do niego zaliczyć szereg uprawnień, ale też obowiązków wynikających ze stosunku zobowiązaniowego z zarządem cmentarza, takich, jak: prawo do użycia „najętego” miejsca na grób w zamian za wynagrodzenie wynikające $\mathrm{z}$ umowy, prawo do dys- o istocie prawa do grobu, jednakże bez względu na skalę oddziaływania pozostają w stosunku do niego zewnętrzne, co prowadzi do wniosku, że prawo do grobu winno być autonomiczne i niezmienne wobec zdarzeń faktycznych.

Konsekwencją samoistnego charakteru prawa do grobu zdaje się przyjęcie jego wyłącznie majątkowej natury. Skoro bowiem złożenie zwłok w grobie sprawia zgodnie z wyrokiem SN, że jest to moment, w którym zmienia się istota prawa do grobu - przy założeniu odrębności elementów niemajątkowych i ich oddziaływania z zewnątrz - prawo do grobu zawsze jest wiązką uprawnień o charakterze majątkowym wynikających z umowy. W konsekwencji bez względu na to, czy w grobie jest już ktoś pochowany, czy też

\section{Konsekwencją samoistnej natury} prawa do grobu jest jego majątkowość.

ponowania pozostałymi miejscami w grobie (przy założeniu grobu pustego albo grobu z wieloma miejscami), prawo do postawienia nagrobka czy przestrzeganie obowiązków wynikających z wzorca umownego, a określonych w regulaminie cmentarza. Prawo do grobu, które zbliżone jest do grupy uprawnień przysługujących najemcy, pozostaje pod wpływem nie tylko uprawnień wynikających z dóbr osobistych bliskich zmarłego (prawo do kultu i czci dla zmarłego, prawo do odwiedzania grobu, prawo do modlitwy przy grobie itd.), ale także prawa do urządzenia pogrzebu zmarłego przez osoby wyliczone w katalogu określonym w ustawie o cmentarzach i chowaniu zmarłych, bądź obowiązku pochowania zmarłego wynikającego z umowy dożywocia czy też woli zmarłego wyrażonej w testamencie. Wszystkie te elementy stanowią wprawdzie

27 Wyrok SN z dnia 7 listopada 2002 r., II CKN 980/00.

28 Odmiennie E. Dołęgowska, K. Klibisz, A. Tworkowska, Cywilnoprawna regulacja prawa do grobu, „Białostockie Studia Prawnicze” 2013, nr 13, s. 122. Autorki stoją na stanowisku, że cechy majątkowe prawa do grobu mają charakter uboczny ab initio. nie, prawo do grobu jest zbywalnym i dziedzicznym przedmiotem obrotu. Taka konstrukcja - oprócz większej spójności i klarowności - zdaje się bardziej intuicyjna dla uczestników obrotu, gdyż prawa majątkowe wynikające $\mathrm{z}$ umowy z zarządem cmentarza pozostaną częścią spadku dziedziczoną na zasadach ogólnych.

W strukturze zaproponowanej przez Sąd Najwyższy dziedziczenie prawa do grobu, w którym zostało już złożone jedno ciało, a pozostają jeszcze wolne miejsca pochówkowe, w przypadku śmierci wyłącznego dysponenta wymaga przeprowadzenia odrębnego postępowanie sądowe na gruncie art. 189 k.p.c., by ustalić, czy powodowi przysługuje prawo do grobu w oparciu o kryterium interesu prawnego. Sądy natomiast, prowadząc takie postępowanie, najczęściej posiłkują się ustawowym kręgiem dziedziczenia czy testamentowymi rozrządzeniami ustanawiającymi dziedzica. Sprawia to, że dochodzi do zdublowania postępowania spadkowego. Tak tedy w drodze stwierdzenia istnienia takiego prawa do grobu sąd de facto rozstrzyga o sukcesji syngularnej dobra niemajątkowego na wypadek śmierci. Bezsensownie obciążane są też sądy okręgowe właściwe dla rozstrzygania takich spraw, tworzony jest 
stan zawieszenia co do tego, kto jest uprawniony do dysponowania prawem, zainteresowani zaś zmuszeni są do poniesienia zbędnych kosztów sądowych związanych z wniesieniem pozwu, które przewyższają opłatę za złożenie wniosku o stwierdzenie nabycia spadku sześciokrotnie ${ }^{29}$.

Klasyfikacja wykształcona w orzecznictwie nie tylko wpływa na stosunki prawne po śmierci wyłącznego dysponenta. Pozwala też przyjąć, że prawo do grobu zawsze, bez względu na okoliczności faktyczne, jest okaże się większa, gdy zbywane miejsce dotyczyć będzie grobu, w którym ktoś został już pochowany ${ }^{30}$. W przypadku grobu, w którym nikogo jeszcze nie pochowano, ograniczenia osobiste - przynajmniej na moment dokonywania transakcji - nie będą ograniczały przedmiotu umowy.

Takie rozszerzenie zbywalności prawa do grobu czy poszczególnych miejsc pochówkowych może się wiązać ze wzrostem ryzyka konfliktu interesów osób bliskich pochowanego już w grobie zmarłego

\section{Ujawniła się potrzeba alternatywnej ścieżki sukcesji syngularnej mortis causa.}

zbywalne. Same umowy zaś mogą dotyczyć majątkowych praw dysponowania miejscami pochówkowymi jak w przedstawionym w sprawie stanie faktycznym. Umowy będą, rzecz jasna, skuteczne wyłącznie między stronami porozumienia - bez związania nimi zarządu cmentarza. Dla tego ostatniego niezmiennie dysponentem pozostanie strona umowy z zarządem, a dopiero w drodze dyspozycji może dojść do złożenia ciała do grobu czy innych czynności związanych $\mathrm{z}$ realizacją prawa do grobu.

Dysponent powinien móc dokonać cesji prawa do grobu w całości w drodze przelewu wierzytelności, umożliwiając tym samym wstąpienie nabywcy w miejsce dłużnika za zgodą zarządu cmentarza i tak przenieść swoje prawo do grobu w całości. Prowadziłoby to w konsekwencji do wpisu nabywcy jako nowego dysponenta. Nabywca tego typu prawa powinien być świadomy szeregu elementów, które mogą je ograniczać, i czynić odpowiednio mniej wartościowym $z$ uwagi na potencjalne obszary konfliktu interesów. Liczba czynników ograniczających

29 Opłata za wniesienie pozwu o ustalenie prawa do grobu zgodnie z art. 26 ust. 1 pkt 6 ustawy o kosztach sądowych w sprawach cywilnych (tekst jedn. Dz.U. z 2019 r., poz. 785 z późn. zm.) wynosi $600 \mathrm{zł}$, podczas gdy odpłata za wniesienie wniosku o stwierdzenie nabycia spadku zgodnie z art. 49 ust. 1 pkt 1 tejże ustawy - 100 zł. i nabywcy jednego z miejsc pochówkowych. Wzrost konfliktów zdaje się wyłącznie pozorny, a jednostkowe przypadki nagannego wykorzystania zbywalności prawa do grobu mogą być zatamowane przez odpowiednie środki prawne i nie powinny przeważać korzyści płynących z koncepcji jednolitego prawa do grobu. Sama koncepcja nie wpływa zatem negatywnie na sytuację prawną bliskich zmarłego oraz na zakres i skuteczność środków prawnych służących ochronie ich praw ${ }^{31}$.

\section{Wnioski}

Rozbieżność między omawianym wyrokiem a glosą krytyczną do niego w postrzeganiu natury prawa do grobu wynika z nieopatrzonego jakimkolwiek uzasadnieniem apriorycznego odrzucenia przez Sąd Najwyższy modelu jednolitego charakteru prawa do grobu - majątkowego bez względu na okoliczności faktyczne. Niemajątkowy charakter prawa do zapełnionego grobu pojedynczego odzwierciedla koncepcję ugruntowaną w prawie rzymskim ${ }^{32}$. Jednakże

30 W takiej tezie tkwi założenie, że tenże grób składa się z więcej niż jednego miejsca pochówkowego.

31 Zob. J. Mazurkiewicz, Non omnis moriar. Ochrona dóbr osobistych zmarłego w prawie polskim, Wrocław 2011, s. 21-81.

32 Tam jednak taka koncepcja nie pozbawiała częściowo zajętego grobu przymiotu dziedziczności. Zob. następujące dwa 
w przypadku grobów składających się z więcej niż jednego miejsca pochówkowego w połączeniu z majątkową koncepcją spadku zaproponowany model prowadzi w praktyce do konieczności wykształcenia alternatywnej ścieżki sukcesji syngularnej mortis causa $\mathrm{w}$ drodze sądowego stwierdzenia istnienia prawa do grobu na podstawie art. 189 k.p.c. Niektórzy dysponenci prawa do grobu, będąc świadomi nieefektywności takiego równoległego postępowania, decydują się na wskazanie sukcesorów prawa do grobu już za życia, dopisując ich w księgach cmentarnych do grona dysponentów. Stanowi to dość czytelny sygnał, że prawo regulujące następstwo prawne tego dobra nie jest adekwatne do potrzeb. Takie skomplikowanie stosowania prawa byłoby zrozumiałe, gdyby szła za nim bardziej skuteczna ochrona konkretnej wartości. Jednak w tym przypadku model niejednolitego charakteru nie pozwala na lepszą ochronę dóbr osobistych związanych z kultem pamięci po zmarłym i równocześnie jest niezwykle niepraktyczny. Prowadzi wszak, w przypadku gdy zmarły jeszcze za życia był wyłącznym dysponentem, do podtrzymania stanu zawieszenia co do tego, kto jest dysponentem prawa do grobu - aż do momentu wydania stosownego orzeczenia przez sąd. Kwestie majątkowe związane z pochówkiem tylko na pierwszy rzut oka zdają się trywialne. Z każdym rokiem organizacja pogrzebu, a szczególnie nabycie miejsca pochówkowego wydają się łączyć z coraz większymi wydatkami, nierzadko przekraczającymi kilkanaście tysięcy złotych. Jednocześnie wartość majątkowa związana z sukcesją prawa do grobu, szczególnie miejsca pochówku, stanowić może nierzadko znaczącą część spadku.

Konstrukcja zaproponowana przez orzecznictwo nie jest najlepszym rozwiązaniem. Przyjęcie przez ustawodawcę jednolitej koncepcji prawa do grobu byłoby dobrą decyzją, służącą usprawnieniu sukcesji prawa do grobu. Skrócenie okresu niepewności co do osoby uprawnionego, zbliżenie zasad rządzących następstwem prawa do grobu do ogólnych zasad sukcesji czy wreszcie zatamowanie fali zbędnych pozwów do sądów okręgowych zdają się wielce

fragmenty: D.11,7,2. Ulpian w księdze dwudziestej piątej oraz D.11,7,5. Gaius w księdze dziewiętnastej do edyktu prowincjonalnego. pożądane. Byłoby to z pewnością bardziej użyteczne niż pozorna próba zapewnienia zwiększonej ochrony dóbr osobistych związanych z kultem pamięci zmarłego, będąca skutkiem odrzucenia jednolitej natury prawa do grobu. Przyjęcie koncepcji jednolitego prawa do grobu pozwoliłoby też na rozwiązanie palącego w naszym kraju problemu wpisów w księgach cmentarnych, które pomimo braku oparcia w ustawie urastają w swej doniosłości i skutkach do rangi wpisów w księgach wieczystych. Szczególnie że część zarządów cmentarzy stoi na stanowisku, że następcy prawni jedynego dysponenta mogą rozporządzać prawem do grobu dopiero od momentu wpisu w księgach cmentarnych, który następuje na podstawie wyroku sądu.

\section{Bibliografia}

Cudny Ł., Kryla K., Kult pamięci osoby zmarłej jako dobro osobiste, „Monitor Prawniczy” 2011, nr 16, s. 897-900.

Darmorost E., Ustawa o cmentarzach i chowaniu zmarlych. Komentarz, Warszawa 2014.

Dołęgowska E., Klibisz K., Tworkowska A., Cywilnoprawna regulacja prawa do grobu, „Białostockie Studia Prawnicze” 2013, nr 13, s. 115-124.

Drembkowski P., Ustawa o cmentarzach i chowaniu zmarlych. Komentarz, Warszawa 2018.

Gołaczyński J. i in., (red.), Non omnis moriar. Osobiste i majątkowe aspekty prawne śmierci człowieka, Wrocław 2015.

Matuszewski K., Pamięć i kult osób zmarlych jako autonomiczne dobro osobiste, „Monitor Prawniczy” 2012, nr 20, s. 1085-1090. Mazurkiewicz J., Non omnis moriar. Ochrona dóbr osobistych zmarłego w prawie polskim, Wrocław 2011.

Osajda K. (red.), Kodeks cywilny. Komentarz, wyd. 24, Warszawa 2020.

Rudnicki S., Prawo do grobu. Zagadnienia cywilistyczne, Kraków 1999.

Sobczak J., Gołda-Sobczak M., Prawo do grobu jako problem kulturowy i prawny, „Zeszyty Naukowe KUL” 2018, t. 60, nr 1 (241), s. 97-220.

Załucki M. (red.), Kodeks cywilny. Komentarz, Warszawa 2019.

\section{Akty prawne}

Ustawa z dnia 31 stycznia 1959 r. o cmentarzach i chowaniu zmarłych (tekst jedn. Dz.U. z 2019 r., poz. 1473).

Ustawa z dnia 23 kwietnia 1964 r. - Kodeks cywilny (tekst jedn. Dz.U. z 2019 r., poz. 1145). 
Ustawa z dnia 17 listopada 1964 r. - Kodeks postępowania cywilnego (tekst jedn. Dz.U. z 2019 r., poz. 1460).

Ustawa o kosztach sądowych w sprawach cywilnych (tekst jedn. Dz.U. z 2019 r., poz. 785 z późn. zm.).

Rozporządzenie Ministra Infrastruktury z dnia 7 marca 2008 r. w sprawie wymagań, jakie muszą spełniać cmentarze, groby i inne miejsca pochówku zwłok i szczątków (Dz.U. z 2008 r., nr 48, poz. 284).

Poselski projekt ustawy z dnia 7 marca 2013 r. o zmianie ustawy o cmentarzach i chowaniu zmarłych (Sejm VII kadencji, druk nr 1661). 